\title{
Which Love Language do You Speak With Your Child? What Are the Effects of your Age, Level of Education, Work Status, and the Number of Children in the Family on the Used Love Languages?
}

\author{
Reham Al-Mohtadi (Corresponding author) \\ School of Education \\ Al- Hussein bin Talal University Jordan. \\ Intisar Turki Al-darabah \\ School of Education \\ Al- Hussein bin Talal University, Jordan
}

Tel: 96-279-810-8464Ｅ-mail: entesusm@yahoo.com

\author{
Khaled Mohamad Hamaden \\ School of Education \\ Middle East University, Jordan
}

Received: December 25, 2018 Accepted: June 6, 2019 Published: June 27, 2019

doi:10.5296/ijld.v9i2.15012ＵRL: https://doi.org/10.5296/ijld.v9i2.15012

\begin{abstract}
The purpose of the current study was to identify which languages of love that the mother used with her child. In addition, it examined the effect of mother's age, level of education, work status, and the number of children in the family on the extent of the mother's use of love languages. The study sample consisted of 729 mothers from the study population. The researchers used a questionnaire instrument that consisted of 105 items that were groups into five dimensions that represent the five love languages proposed by Gary Chapman, (1992). The researchers adopted and adjusted five love languages questionnaire to make it appropriate to be used in the Arab world. The questionnaire instrument was presented to panel of experts to check its validity. Appropriate statistical analysis methods were performed on participants'
\end{abstract}


responses to the questionnaire.

The findings showed that the most common type of love language that the mothers used to speak with their children was "acts of service", while the least common type of love language that the mothers used to speak with their children was "words of affirmation". In addition, the results showed that there were no significant differences in the extent of the mother's use of love languages based on mother's age, level of education, work status, and the number of children in the family. Based on the findings, the study provided some recommendations that were related to the important guidance roles of the institutions, centers and associations that concerned with the childhood sector and the parental relationship. These institutions, centers and associations should conduct training sessions and seminars that aim to discuss the nature of the relationship between mothers and their children. They should publish more training manuals and records that discuss the concept of love between the mother and her child and improve parents understanding of the love relationship between the mother and her child. Another important recommendation was related to the need to conduct more research studies to understand the relationship between the mother and her child.

Keywords: love languages, words of affirmation, quality time, receiving gifts, acts of service and physical touch.

\section{Introduction}

Some parents believe that love means providing clothes and gifts to their children, while they ignore the sentimental part of love that is related to express their emotions and feelings to their children (Chapman, 1992). One of the most important needs that a child need to in order to strength his/her personality is the emotional satisfaction of love and compassion, where mother should satisfy her children's emotional needs in order to make them feel safe and comfortable (Chapman, 1992).

Raising children depends on the love relationship between these children and their parents, the child who feels loved would accomplish the desired results (Nichole \& Denise, 2006). The parents naturally love their children. However, sometimes the children may not feel loved since the parents fail to communicate their love to their children (Chapman, 1992; Deborah, 2000). Typically, satisfying children's physical needs is easy for their parents, but physical needs are not the only significant needs for the children (Chapman, 1992; Dainton, 2000). Parents' use of love languages with their children does not mean that these children would not rebel against their parents in the future, but parents' use of love languages with their children means that theses children will feel that they are loved and that would enhance their feelings of hope and safety (Chapman,1992; Backett, 1982). Making the children feel loved would help raising them to be responsible individuals. Love is the essence of the relationship between the parents and their children. When parents speak the child's love language, they fill his/her emotional reservoir with love (Brannen \& Moss 1987). Children who feel loved would respond better to parental discipline and refinement compared to the children who do not feel loved.

Therefore, the parents, particularly mothers, need to learn about the five love languages and the most common language that they used with their children (Chodorow, 1978; Chodorow, 1989). 


\section{Macrothink}

However, love can be communicated using more than one love language (Dainton, 2000; Chapman, 1992). The children would feel loved through the use of different types of love languages (Chapman, 1992). Therefore, parents need to learn about the different types of love language to in order to improve their communication with their children. Parents need to learn about the main type of love languages that they use with their children and the factors that would influence the levels of their use of the different types of love languages with their children. The current study focused on the mothers' use of love languages with her children.

\section{Theoretical Framework}

Love can be communicated to the child using at least one of the five love languages (Chapman, 1992). The five love languages include physical touch, words of affirmation, quality time, receiving gifts, and acts of service (Chapman, 1992). Physical touch is the simplest expression of love that can be used without conditions. Physical touch is not limited to hugging and kissing, but it includes any form of physical communication such as friendly pat on the shoulder. Words of affirmation have great power to express love, where words of encouragement, appreciation, praise and compliment as well as the words that express positive attitudes toward the child would mean to him/her that "I do care about you" (Chapman,1992; Crouch, \& Manderson 1993). The mother can express her love to her child through using quality time, where giving the child enough attentions through spending time playing and talking to him/her is a way to express her love to the child (Daly, 1993; Ehrensaft, 1995). Receiving gifts is another type of love languages, where the only way for some children to feel loved is to receive gifts (Chapman, 1992). However, giving gifts for the child should be associated with expressions of love and the gifts should be given to the child with the presence of the whole family. In addition, the parents should choose the right gifts for their child (Daly, 1993). Acts of service involve helping the child accomplishing tasks that he/she cannot do by $\mathrm{him} /$ herself. Through the language of acts of service, the child would learn how to help others in the family and how to be mature and responsible. In addition, it is important to teach the child how to help others (Chapman, 1992). Satisfying the child's needs of love and tenderness would make him/her obedient, cooperative and would improve his/her discipline. Therefore, expressing compassion and love to the child is a cornerstone of his/her education, where expressing compassion and love to the child would help in understanding his/her actions and in earning his/her trust (Everingham, 1994; Hays, 1996)

\section{Problem of the Study}

Changes in lifestyle and the effect of technological advancements have led to increase in the social distance and limitations in expressing personal feelings in the society, where people are becoming cold hearted and their relationships are characterized by being free of feelings. Many mothers are not provided with appropriate guidance to express their feelings to and strengthen their association with their children. Nowadays children might not have gotten much physical touching from their fathers compared to the older generations, where nowadays fathers are working for long hours and they are returning home exhausted.

Research studies have shown that the children, who have received affection, tenderness, closeness, and physical interaction with their teachers or relatives, have had a much better 
social and emotional development than those who have been deprived of such forms of love (McMahon, 1995; Ribbens, 1994). Moreover, the behaviors and personality characteristics of adult people are strongly associated with their experiences during their childhood. Happy children have positive emotions, high self-confidence skills, flexible personality, and skills of optimism.

\section{Importance of the Study}

Raising children with love would help them in their emotional reconciliation process. Raising children with love would make them able to react properly to their different and sudden emotions states. Raising children with love would teach the children how to show stable reactions to different emotions such as love, jealousy, anger, fear and depression, which the child naturally faces.

Social and emotional development of the child would determine the characteristics of his/her future personality in terms of being brave or fearful, selfish or collaborator, a person who love to control others or a person who love to work and cooperate with others, and a person who would accepts criticism or a person who are constantly tense and anxious.

The parents should be very careful in dealing with children between the ages of 2 and 6 years, where this stage of age is very sensitive stage of development, where this stage is considered as the most important stage in the lives of children. Children between the two and six years old would start to learn the moral values, to use their imagination and to shape their emotions.

Richards, (1978), Verheyen, (1987), Lupton, and Barclay (1997), and Ribbens, (1994), reported that the emotions of children between the ages of 2 and 6 years would overcome their logic, where the children at this stage would be spontaneous and having volatile mood. In addition at this stage of age, the children would develop complex emotions like the sense of a deficiency and guilt, anger and fear, envy and jealousy". These feelings are spontaneous reactions from children to express their frustrating feelings that they hide and reject at the same time.

Every mother would like to have a perfect child who is quiet and obedient and who do not make mistakes (Hays, 1996; Komter, 1987). However, the mother would be disappointed when she feels that her child does not behave as she expected (Everingham, 1994). Mothers need to learn that the child would acquire his/her behaviors and the ways of expressing his/her feelings from observing the adults around him/her. The mother is the first person that the child would take as model in his/her behaviors and he/she would imitate her (Crouch \& Manderson 1993).

\section{Purpose of the Study}

The aim of the current study was to answer the following research questions:

1. What are the levels of mothers' use of five love languages (words of affirmation, quality time, receiving gifts, acts of service, physical touch) with their children?

2. Are there any statistically significant differences at $(\alpha=0.05)$ in participants' levels of using the five love languages based on their age? 


\section{Macrothink}

International Journal of Learning and Development

3. Are there any statistically significant differences at $(\alpha=0.05)$ in participants' levels of using the five love languages based on the number of the children in their family?

4. Are there any statistically significant differences at $(\alpha=0.05)$ in participants' levels of using the five love languages based on their educational level?

5. Are there any statistically significant differences at $(\alpha=0.05)$ in participants' levels of using the five love languages based on their work status?

\section{Research Methodology}

The researchers used descriptive survey research approach. Descriptive survey research approach was appropriate for the nature of the current research queries.

\subsection{Study Sample}

The study sample consisted of 729 mothers who had at least one child between the ages of two to six years old. Table 1 shows the distribution of participating mothers based on the Jordanian governorate that they were from.

Table 1. The distribution of Participating Mothers based on the Jordanian Governorate that they were from.

\begin{tabular}{ll}
\hline Governorate & Number of mothers \\
\hline Amman & 200 \\
Irbid & 160 \\
Karak & 119 \\
Ma'an & 100 \\
Aqaba & 15 \\
Total & 729 \\
\hline
\end{tabular}

\subsection{Study Instrument}

Participants' agreements to the questionnaire' items were measured using three-point Likert scale, where the responses options for each questionnaire's item were: 1 for disagree, 2 for neutral, and 3 for agree. The following equation was used to describe participants' level of approval to the questionnaire' items 


$$
\text { The length of interval }=\frac{\text { highest value-lowest value }}{\text { number of levels }}=\frac{3-1}{3}=0.66
$$

Based on the result of the above equation, the following descriptions of the levels for participants' approval to the questionnaire' items were adopted:

- Between 1 and 1.66 - Low

- Between 1.67 and 2.33-Moderate

- Between 2.34 and 3 - High

In order to examine the reliability of the used questionnaire and the internal consistency of the questionnaire's, Cronbach's alpha coefficients were computed for the collected data from a pilot sample that consisted of 150 mothers who were not part of the current study. The values of the Cronbach's alpha reliability coefficients were high and appropriate for the purpose of the current study. Table 2 shows the values of Cronbach's Alpha reliability coefficients.

Table 2. The Values of Cronbach's Alpha Reliability Coefficients for the Questionnaire's Scales.

\begin{tabular}{ll}
\hline Scale & Internal consistency \\
\hline Words of affirmation & 0.99 \\
Quality time & 0.98 \\
Receiving gifts & 0.98 \\
Acts of service & 0.98 \\
Physical touch & 0.98 \\
Overall & 0.99
\end{tabular}

\subsection{Study Sample}


Table 3. The Frequency and Percentage of the Participants distributed based

\begin{tabular}{llll}
\hline & Categories & Frequency & Percentage \\
\hline \multirow{3}{*}{ Mother 's age } & 18-30 years old & 180 & 24.7 \\
& 31-45 years old & 254 & 34.8 \\
& 45 years old & 295 & 40.5 \\
\hline \multirow{2}{*}{$\begin{array}{l}\text { Number of children in } \\
\text { family }\end{array}$} & One child & 135 & 18.5 \\
& Two to three children & 313 & 42.9 \\
& Four children or more & 281 & 38.5 \\
\hline \multirow{2}{*}{ Mother's Educational level } & Educated & 289 & 39.6 \\
& Un-educated & 440 & 60.4 \\
\hline \multirow{2}{*}{ Mother's work Status } & Working & 293 & 40.2 \\
& Not working & 436 & 59.8 \\
& Overall & 729 & 100.0 \\
\hline
\end{tabular}

\section{Results}

First research question: "What are the levels of mothers' use of five love languages with their children?"

In order to answer the first research question, means and standard deviations were computed for mothers' responses to each scale in the questionnaire. Table 4 shows the means and standard deviation of mothers' responses to each scale in the questionnaire that measured levels of mothers' use of the five love languages.

Table 4. Means and Standard Deviations of Mothers' Responses to the Levels of their Use of Love Languages with their Children

\begin{tabular}{llllll}
\hline Rank & Number & Scale & Mean & SD & Level \\
\hline 1 & 3 & Acts of service & 2.35 & .74 & High \\
2 & 4 & Physical touch & 2.32 & .74 & Moderate \\
3 & 2 & Quality time & 2.24 & .63 & Moderate \\
4 & 3 & Receiving gifts & 2.23 & .70 & Moderate \\
5 & 2 & Words of affirmation & 2.16 & .69 & Moderate \\
& & Overall & 2.25 & .68 & Moderate \\
\hline
\end{tabular}

The results showed that the means of the participants' levels of using the five love languages ranged between $(M=2.35, S D=.74)$ to $(M=2.16, S D=.69)$. The mothers responded most positively to "Acts of service" scale $(M=2.35, S D=0.74)$. The mothers responded least positively to "Words of affirmation" scale $(M=2.16, S D=.69)$. The level of overall mean of the participants' use o five love languages was moderate $(M=2.25, S D=0.68)$.

Second research question: "Are there any statistically significant differences at $(\alpha=0.05)$ in 
participants' levels of using the five love languages based on their age?

In order to answer the second research question, means and standard deviations were computed for mothers' responses to each scale in the questionnaire based on their age. Table 5 shows the means and standard deviation of mothers' responses to five love languages scales based on their age.

Table 5. Means and Standard Deviations of Mothers' Responses to the Levels of their Use of the Five Love Languages with their Children based on their Age

\begin{tabular}{|c|c|c|c|c|}
\hline Scale & Categories & Number & Mean & SD \\
\hline \multirow[t]{4}{*}{ Words of affirmation } & $18-30$ years old & 180 & 2.16 & .72 \\
\hline & $31-45$ years old & 254 & 2.20 & .678 \\
\hline & 45 years old & 295 & 2.14 & .69 \\
\hline & Overall & 729 & 2.16 & .69 \\
\hline \multirow[t]{4}{*}{ Quality time } & $18-30$ years old & 180 & 2.22 & .65 \\
\hline & $31-45$ years old & 254 & 2.28 & .61 \\
\hline & 45 years old & 295 & 2.22 & .63 \\
\hline & Overall & 729 & 2.24 & .63 \\
\hline \multirow[t]{4}{*}{ Receiving gifts } & $18-30$ years old & 180 & 2.21 & .74 \\
\hline & $31-45$ years old & 254 & 2.27 & .68 \\
\hline & 45 years old & 295 & 2.21 & .70 \\
\hline & Overall & 729 & 2.23 & .70 \\
\hline \multirow[t]{4}{*}{ Acts of service } & 18-30 years old & 180 & 2.32 & .78 \\
\hline & $31-45$ years old & 254 & 2.40 & .72 \\
\hline & 45 years old & 295 & 2.33 & .73 \\
\hline & Overall & 729 & 2.35 & .74 \\
\hline \multirow[t]{4}{*}{ Physical touch } & $18-30$ years old & 180 & 2.28 & .78 \\
\hline & $31-45$ years old & 254 & 2.36 & .71 \\
\hline & 45 years old & 295 & 2.31 & .74 \\
\hline & Overall & 729 & 2.32 & .74 \\
\hline \multirow[t]{4}{*}{ Overall } & $18-30$ years old & 180 & 2.22 & .72 \\
\hline & $31-45$ years old & 254 & 2.29 & .66 \\
\hline & 45 years old & 295 & 2.23 & .68 \\
\hline & Overall & 729 & 2.25 & .68 \\
\hline
\end{tabular}




\section{Macrothink}

International Journal of Learning and Development

ISSN 2164-4063 2019, Vol. 9, No. 2

Table 5 shows that there were variations in the means of mothers' responses to the levels of their use the five love languages with their children based on their age. Analysis of variance (ANOVA) was carried out to check whether these differences were statistically significant at $(\alpha=0.05)$ (Table 6).

Table 6. One-Way ANOVA- Mothers' Responses to the Levels of their Use of the Five Love Languages with their Children based for their Age

\begin{tabular}{|c|c|c|c|c|c|c|}
\hline Scale & Groups & Sum of squares & Degrees of freedom & Mean Square & $\mathbf{F}$ & Sig. \\
\hline \multirow[t]{3}{*}{ Words of affirmation } & Between groups & .622 & 2 & .31 & & \\
\hline & within groups & 350.49 & 726 & .48 & .64 & .53 \\
\hline & Overall & 351.11 & 728 & & & \\
\hline \multirow[t]{3}{*}{ Quality time } & Between groups & .584 & 2 & .29 & & \\
\hline & within groups & 286.20 & 726 & .39 & .74 & .48 \\
\hline & Overall & 286.78 & 728 & & & \\
\hline \multirow[t]{3}{*}{ Receiving gifts } & Between groups & .60 & 2 & .30 & & \\
\hline & within groups & 358.12 & 726 & .49 & .61 & .54 \\
\hline & Overall & 358.72 & 728 & & & \\
\hline \multirow[t]{3}{*}{ Acts of service } & Between groups & .80 & 2 & .40 & & \\
\hline & within groups & 397.57 & 726 & .55 & .73 & .48 \\
\hline & Overall & 398.37 & 728 & & & \\
\hline \multirow[t]{3}{*}{ Physical touch } & Between groups & .91 & 2 & .45 & & \\
\hline & within groups & 398.51 & 726 & .55 & .83 & .44 \\
\hline & Overall & 399.4 & 728 & & & \\
\hline \multirow[t]{3}{*}{ Overall } & Between groups & .64 & 2 & .32 & & \\
\hline & within groups & 338.41 & 726 & .47 & .69 & .50 \\
\hline & Overall & 339.05 & 728 & & & \\
\hline
\end{tabular}

Table 6 shows that there were no significant differences in the levels of mothers' use of the five love languages with their children for their age. In addition, there were no significant differences in the overall mothers' use of love languages for their age.

Third research question: "Are there any statistically significant differences at $(\alpha=0.05)$ in participants' levels of using the five love languages based on the number of the children in their family?

In order to answer the third research question, means and standard deviations were computed for mothers' responses to each scale in the questionnaire based on the number of the children in 
their family. Table 7 shows the means and standard deviation of mothers' responses to five love languages scales based on the number of the children in their family.

Table 7. Means and Standard Deviations of Mothers' Responses to the Levels of their Use of the Five Love Languages with their Children based on the Number of the Children in their Family

\begin{tabular}{|c|c|c|c|c|}
\hline Scale & Categories & Number & Mean & SD \\
\hline \multirow[t]{4}{*}{ Words of affirmation } & One child & 135 & 2.18 & .68 \\
\hline & Two to three children & 313 & 2.16 & .69 \\
\hline & Four children or more & 281 & 2.16 & .71 \\
\hline & Overall & 729 & 2.16 & .69 \\
\hline \multirow[t]{4}{*}{ Quality time } & One child & 135 & 2.26 & .62 \\
\hline & Two to three children & 313 & 2.24 & .62 \\
\hline & Four children or more & 281 & 2.23 & .64 \\
\hline & Overall & 729 & 2.24 & .63 \\
\hline \multirow[t]{4}{*}{ Receiving gifts } & One child & 135 & 2.24 & .69 \\
\hline & Two to three children & 313 & 2.23 & .70 \\
\hline & Four children or more & 281 & 2.23 & .71 \\
\hline & Overall & 729 & 2.23 & .70 \\
\hline \multirow[t]{4}{*}{ Acts of service } & One child & 135 & 2.35 & .72 \\
\hline & Two to three children & 313 & 2.36 & .74 \\
\hline & Four children or more & 281 & 2.35 & .75 \\
\hline & Overall & 729 & 2.35 & .74 \\
\hline \multirow[t]{4}{*}{ Physical touch } & One child & 135 & 2.34 & .74 \\
\hline & Two to three children & 313 & 2.32 & .74 \\
\hline & Four children or more & 281 & 2.31 & .74 \\
\hline & Overall & 729 & 2.32 & .74 \\
\hline \multirow[t]{4}{*}{ Overall } & One child & 135 & 2.26 & .67 \\
\hline & Two to three children & 313 & 2.25 & .68 \\
\hline & Four children or more & 281 & 2.24 & .69 \\
\hline & Overall & 729 & 2.25 & .68 \\
\hline
\end{tabular}

Tables 7 shows that there were variations in the means of mothers' responses to the levels of their use the five love languages with their children based on the number of the children in their 
family, Analysis of variance (ANOVA) was carried out to check whether these differences were statistically significant at $(\alpha=0.05)$ (Table 8$)$.

Table 8. One-Way ANOVA- Mothers' Responses to the Levels of their Use of the Five Love Languages with their Children for the Number of Children in their Family

\begin{tabular}{|c|c|c|c|c|c|c|}
\hline Scale & Groups & Sum of squares & Degrees of freedom & Mean Square & $\mathbf{F}$ & Sig. \\
\hline \multirow[t]{3}{*}{ Words of affirmation } & Between groups & .07 & 2 & .03 & \multirow{3}{*}{.07} & \multirow{3}{*}{.93} \\
\hline & within groups & 351.047 & 726 & .48 & & \\
\hline & Overall & 351.11 & 728 & & & \\
\hline \multirow[t]{3}{*}{ Quality time } & Between groups & .064 & 2 & .03 & \multirow{3}{*}{.08} & \multirow{3}{*}{.92} \\
\hline & within groups & 286.72 & 726 & .40 & & \\
\hline & Overall & 286.78 & 728 & & & \\
\hline \multirow[t]{3}{*}{ Receiving gifts } & Between groups & .020 & 2 & .01 & \multirow{3}{*}{.02} & \multirow{3}{*}{.98} \\
\hline & within groups & 358.70 & 726 & .49 & & \\
\hline & Overall & 358.72 & 728 & & & \\
\hline \multirow[t]{3}{*}{ Acts of service } & Between groups & .01 & 2 & .004 & \multirow{3}{*}{.01} & \multirow{3}{*}{.99} \\
\hline & within groups & 398.36 & 726 & .55 & & \\
\hline & Overall & 398.37 & 728 & & & \\
\hline \multirow[t]{3}{*}{ Physical touch } & Between groups & .10 & 2 & .051 & \multirow{3}{*}{.09} & \multirow{3}{*}{.91} \\
\hline & within groups & 399.31 & 726 & .55 & & \\
\hline & Overall & 399.41 & 728 & & & \\
\hline \multirow[t]{3}{*}{ Overall } & Between groups & .041 & 2 & .021 & \multirow{3}{*}{.04} & \multirow{3}{*}{.96} \\
\hline & within groups & 339.01 & 726 & .47 & & \\
\hline & Overall & 339.05 & 728 & & & \\
\hline
\end{tabular}

Table 8 shows that there were no significant differences in the levels of mothers' use of the five love languages with their children for the number of the children in their family. In addition, there were no significant differences in the overall mothers' use of love languages for the number of the children in their family.

Fourth research question: "Are there any statistically significant differences at $(\alpha=0.05)$ in participants' levels of using the five love languages based on their educational level?

In order to answer the fourth research question, means and standard deviations were computed for mothers' responses to each scale in the questionnaire based on their educational level. In addition, t-tests were conducted to examine the differences in in the means of mothers' responses to the levels of their use the five love languages with their children based on their 
educational level (Educated Un-educated) (Table 9)

Table 9. Means and Standard Deviations and Results of T-Tests of Mothers' Responses to the Levels of their Use of the Five Love Languages with their Children based on their Educational Level

\begin{tabular}{|c|c|c|c|c|c|c|c|}
\hline Scale & Mother's Educational level & $\mathrm{n}$ & $\mathrm{M}$ & SD & $\mathrm{t}$ & $\mathbf{F}$ & Sig \\
\hline \multirow[t]{2}{*}{ Words of affirmation } & Educated & 289 & 2.13 & .71 & \multirow{2}{*}{-1.06} & \multirow{2}{*}{727} & \multirow{2}{*}{.29} \\
\hline & Un-educated & 440 & 2.19 & .68 & & & \\
\hline \multirow[t]{2}{*}{ Quality time } & Educated & 289 & 2.21 & .64 & \multirow{2}{*}{-1.05} & \multirow{2}{*}{727} & \multirow{2}{*}{.30} \\
\hline & Un-educated & 440 & 2.26 & .62 & & & \\
\hline \multirow[t]{2}{*}{ Receiving gifts } & Educated & 289 & 2.20 & .72 & \multirow{2}{*}{-1.08} & \multirow{2}{*}{727} & \multirow{2}{*}{.28} \\
\hline & Un-educated & 440 & 2.26 & .69 & & & \\
\hline \multirow[t]{2}{*}{ Acts of service } & Educated & 289 & 2.31 & .76 & \multirow{2}{*}{-1.24} & \multirow{2}{*}{727} & \multirow{2}{*}{.22} \\
\hline & Un-educated & 440 & 2.38 & .73 & & & \\
\hline \multirow[t]{2}{*}{ Physical touch } & Educated & 289 & 2.28 & .76 & \multirow{2}{*}{-1.22} & \multirow{2}{*}{727} & \multirow{2}{*}{.23} \\
\hline & Un-educated & 440 & 2.35 & .73 & & & \\
\hline \multirow[t]{2}{*}{ Overall } & Educated & 289 & 2.21 & .70 & \multirow{2}{*}{-1.12} & \multirow{2}{*}{727} & \multirow{2}{*}{.26} \\
\hline & Un-educated & 440 & 2.27 & .67 & & & \\
\hline
\end{tabular}

Table 9 shows that there were no significant differences in the levels of mothers' use of the five love languages with their children based on their educational level. In addition, there were no significant differences in the overall mothers' use of love languages for their educational level.

Fifth research question: "Are there any statistically significant differences at $(\alpha=0.05)$ in participants' levels of using the five love languages based on their work status?

In order to answer the fifth research question, means and standard deviations were computed for mothers' responses to each scale in the questionnaire based on their work status. In addition, t-tests were conducted to examine the differences in in the means of mothers' responses to the levels of their use the five love languages with their children based on their work status (working or not working) (Table 10) 
Table 10. Means and standard deviations and results of t-tests of mothers' responses to the levels of their use the five love languages with their children based on their work status

\begin{tabular}{|c|c|c|c|c|c|c|c|}
\hline Scale & Mother's work & $\mathrm{n}$ & $\mathrm{M}$ & SD & $\mathrm{t}$ & $\mathbf{F}$ & Sig \\
\hline \multirow{2}{*}{ Words of affirmation } & Working & 293 & 2.22 & .68 & \multirow[t]{2}{*}{1.62} & \multirow[t]{2}{*}{727} & \multirow[t]{2}{*}{.11} \\
\hline & Not working & 436 & 2.13 & .70 & & & \\
\hline \multirow{2}{*}{ Quality time } & Working & 293 & 2.29 & .61 & \multirow[t]{2}{*}{1.68} & \multirow[t]{2}{*}{727} & \multirow[t]{2}{*}{.09} \\
\hline & Not working & 436 & 2.21 & .64 & & & \\
\hline \multirow{2}{*}{ Receiving gifts } & Working & 293 & 2.28 & .69 & \multirow[t]{2}{*}{1.54} & \multirow[t]{2}{*}{727} & \multirow[t]{2}{*}{.12} \\
\hline & Not working & 436 & 2.20 & .71 & & & \\
\hline \multirow{2}{*}{ Acts of service } & Working & 293 & 2.40 & .73 & \multirow[t]{2}{*}{1.57} & \multirow[t]{2}{*}{727} & \multirow[t]{2}{*}{.12} \\
\hline & Not working & 436 & 2.32 & .75 & & & \\
\hline \multirow{2}{*}{ Physical touch } & Working & 293 & 2.37 & .72 & \multirow[t]{2}{*}{1.45} & \multirow[t]{2}{*}{727} & \multirow[t]{2}{*}{. .15} \\
\hline & Not working & 436 & 2.29 & .75 & & & \\
\hline Overall & Working & 293 & 2.30 & .67 & 1.60 & 727 & .11 \\
\hline
\end{tabular}

Table 10 shows that there were no significant differences in the levels of mothers' use of the five love languages with their children based on their work status. In addition, there were no significant differences in the overall mothers' use of love languages for their working status.

\section{Discussion}

The findings showed that the most common type of love languages that the mothers used to speak with their children was "acts of service", while the least common type of love languages that the mothers used to speak with their children was "words of affirmation". A possible explanation of the result is that the parents would express their love to their children through doings things for them that the children cannot do by themselves. The parents would express their love to their children through preparing food for them and paying their school expenses. Some mother would feel grateful for providing her children with different types of services. These mothers would express their love to their children through washing dishes and cleaning the house. Furthermore, the mothers who use acts of service to express their love to their children would like to do nice things for their children such as helping them in their home works and school projects and giving them rides. These mothers would believe that acts of services would fill their children's emotional reservoirs with love

Regarding the effects of mother's age, mother's educational level, number of children in the family, and mother's work status on the extent of the mothers' use of love languages, the results showed that these variables would not affect the extent of the mothers' use of love languages. 


\section{Macrothink}

\section{Recommendation of the Study}

Based on the findings, the study suggested the following recommendations:

- The need to emphasize on the important guidance roles of the institutions, centers and associations that concerned with the childhood sector and the parental relationship. These institutions, centers and associations should conduct training sessions and seminars that aim to discuss the nature of the relationship between mother and her child. These training sessions should particularly target newly married couples.

- There is a need to publish more training manuals and records that discuss the concept of love between the mother and her child and improve parents understanding of love relationship with their children.

- There is a need to conduct more research studies to understand the relationship between the mothers and their children. In addition, there is need to introduce and examine new concepts related to love between the mother and their children such as the concepts of giving love, punishment as an act of love, blocking love, equality of the child with passion.

\section{References}

Chapman, G. (1992). The five love languages: How to express heartfelt commitment to your mate. Chicago: Northfield Publishin.

Nichole, E., \& Denise, P. (2006). Speaking the Language of Relational Maintenance: A Validity Test of Chapman's (1992) Five Love Languages. Communication Research Reports, 23, 2006 - 1. https://doi.org/10.1080/17464090500535822

Deborah, L. (2000). A love/hate relationship: the ideals and experiences of first- time mothers. Journal of Sociology, 36(1), 50-63. https://doi.org/10.1177/144078330003600104

Dainton, M. ( 2000 ). Maintenance behaviors, expectations for maintenance, and satisfaction: Linking comparison levels to relational maintenance strategies. Journal of Social and Personal Relationships, 17, 827-842. https://doi.org/10.1177/0265407500176007

Backett, K. (1982). Mothers and Fathers: A Study of the Development and Negotiation of Parental Behaviour. London: Macmillan. https://doi.org/10.1007/978-1-349-05204-2 PMid: 7079215

Boulton, M. (1983). On Being a Mother: A Study of Women with Pre-School Children. London: Tavistock.

Brannen, J., \& Moss, P. (1987). Fathers in Dual-earner Households: Through Mothers' Eyes' in C. Lewis and M. O'Brien (eds), Reassessing Fatherhood: New Observations on Fathers and the Modern Family. London: Sage.

Chodorow, N. (1978). The Reproduction of Mothering Berkeley. University of California Press 


\section{Macrothink}

International Journal of Learning and Development

ISSN 2164-4063 2019, Vol. 9, No. 2

Crouch, M., \& Manderson, L. (1993). New Motherhood: Cultural and Personal Transitions in the 1980s. Camberwell, Victoria: Gordon and Breach Science Publishers

Daly, K. (1993) Reshaping Fatherhood: Finding the Models'. Journal of Family Issues, 14(4), 510-30. https://doi.org/10.1177/019251393014004003

Everingham, C. (1994). Motherhood and Modernity Sydney: Allen and Unwin.

ays, S. (1996). The Cultural Contradictions of Motherhood New Haven. Yale University Press.

Komter, A. (1987). Why Bad Mothers Are Worse than Bad Fathers: Power Mechanisms in the Family' in T. Knijn and A.-C. Mulder (eds). Unraveling Fatherhood Dordrecht, TheNetherlands: Foris.

Lewis, C. (1986). Becoming a Father Milton Keynes. Open University Pres

Lupton, D., \& Barclay, L. (1997). Constructing Fatherhood: Discourses and Experiences. London: Sage

McMahon, M. (1995). Engendering Motherhood: Identity and Self-Transformation in Women's Lives. New York: The Guilford Press.

Ribbens, J. (1994). Mothers and Their Children: A Feminist Sociology of Childrearing. London: Sage.

Richards, L. (1978). Having Families: Marriage, Parenthood and Social Pressures in Australia. Ringwood: Penguin

Verheyen, C. (1987). Mother Knows Best: For Him the Play, for Her the Rest' in T. Knijn and A.-C. Mulder (eds.), Unravelling Fatherhood Dordrecht. The Netherlands: Foris: 37-47.

Walzer, S. (1996). Thinking About the Baby: Gender and Divisions of Infant Care'. Social Problems, 43(2), 219-34. https://doi.org/10.2307/3096999

Weedon, C. (1992). Feminist Practice and Poststructuralist. Theory Oxford: Blackwell

Wearing, B. (1984). The Ideology of Motherhood Sydney. George Allen and Unwin

White, N. (1994) About Fathers: Masculinity and the Social Construction of Fatherhood' Australian and New Zealand. Journal of Sociology, 30(2), 119-31. https://doi.org/10.1177/144078339403000202

Woodward, K. (1997). Motherhood: Identities, Meanings and Myths' in K. Woodward (ed.) Identity and Difference. London: Sage.

Young, I. (1990). Throwing Like a Girl and Other Essays in Feminist Philosophy and Social Theory. Bloomington: Indiana University Press 


\section{Macrothink}

International Journal of Learning and Development

\section{Copyright Disclaimer}

Copyright for this article is retained by the author(s), with first publication rights granted to the journal.

This is an open-access article distributed under the terms and conditions of the Creative Commons Attribution license (http://creativecommons.org/licenses/by/4.0/). 